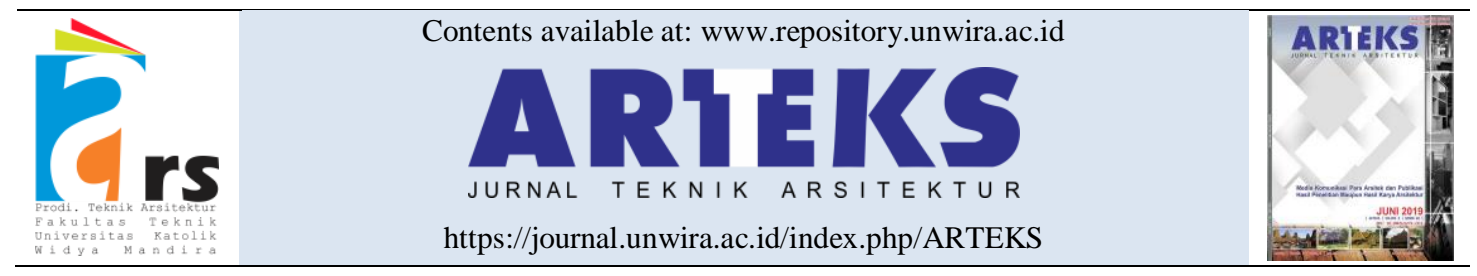

Research paper

doi: 10.30822/arteks.v5i3.582

\title{
Indoor health and comfort for the green workplace at university
}

\section{Dyah Kusuma Wardhani ${ }^{(D)}$, Susan*, Michelle Anastasia, Michele Julian Setiando}

Interior Architecture Universitas Ciputra Surabaya

CitraLand CBD Boulevard, Made, Surabaya, Indonesia

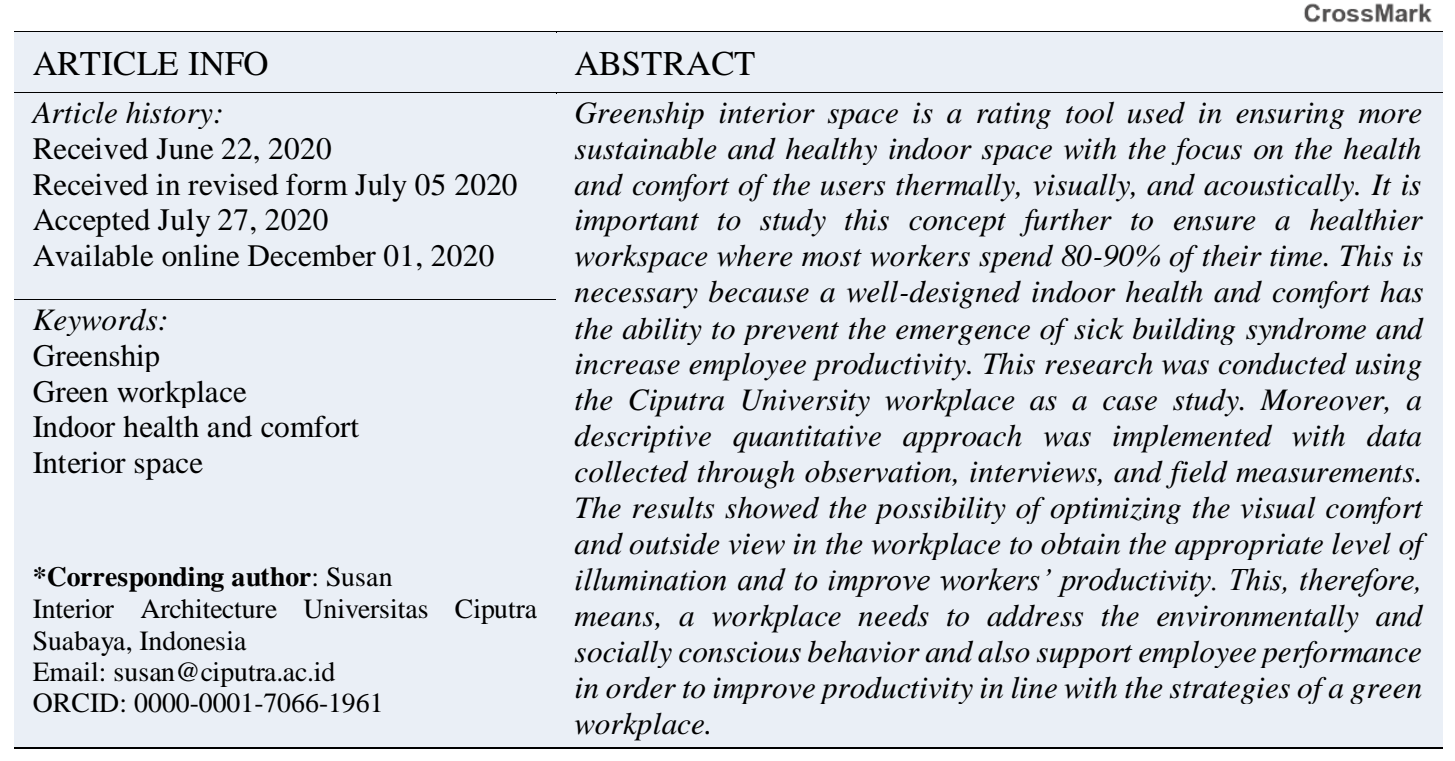

\section{Introduction}

Buildings have been observed to be a major factor mitigating climate change and this has led to increased attention to its design, performance, and evaluation (Yuliani, Hardiman, and Setyowati 2020). This also caused the need for green buildings which are characterized by energy and resource efficiency as well as the need for a comfortable, healthy, and productive environment (Subroto 2019; Pradono 2019). According to the Green Building Index (2014), buildings are very influential to the health of space users while the ability to sustain this space is determined by human existence and their activities (GBI 2014). The concept of sustainability for Interior Space based on the Green Building Council Indonesia (2016) primarily aims to (1) protect human health and comfort (2) reduce pollution and environmental damage, and (3) reduce energy and resources
(Green Building Council Indonesia 2017). Moreover, the assessment parameters for Greenship Interior Space consist of 6 criteria which are the Appropriate Site Development (ASD), Energy Efficiency and Conservation (EEC), Water Conservation (WAC), Material and Resources Cycle (MRC), Building and Environment Management (BEM), and Indoor Health and Comfort (IHC) which is the criterion with the highest rating points (Figure 1). 




Figure 1. Greenship interior space assessment criteria Source: (Green Building Council Indonesia 2017)

These criteria have become a very important reference for sustainable design due to their ability to ensure energy and resource savings, reduction in building operating costs, improvement in the health and comfort of users, and increment in workers' productivity. "The Business Case for Green Building" reported buildings with a green concept to have the ability of enhancing health and productivity of the occupants (World Green Building Council 2013). It has also been reported that users are also more satisfied with their environmental quality, especially the interior as a whole. This is majorly due to the fact that green buildings provide better quality lighting, ventilation as well as $\mathrm{CO} 2$ and VOC concentrations in space (Lim et al. 2012)

Most of human activities reported to be taking $70-90 \%$ of their time are conducted indoor (Darus, Ahmed, and Latif 2011). This makes indoor health and comfort very important to the users and a matter of concern to the Green Building Council Indonesia, especially with the focus on assessing the Greenship of interior space. The organization reported the possibility of having pollutants from both inside and outside sources with those associated with air in the warm humid climate country assumed to be mainly from the mechanical ventilation system designed to minimize air infiltration and reduce cooling load energy. Indoor Air Quality and Comfort assessment tools are designed to prevent air quality problems and protect the occupants' health using the following 12 criteria (Table 1).
Table 1. Indoor health and comfort criteria

\begin{tabular}{lll}
\hline Code & Criteria & Credits \\
\hline IHC P & No Smoking Campaign & $\mathrm{P}$ \\
\hline IHC 1 & $\begin{array}{l}\text { Outdoor } \\
\text { Introduction }\end{array}$ & 1 \\
\hline IHC 2 & CO2 Monitoring & 2 \\
\hline IHC 3 & Chemical Pollutant & 9 \\
\hline IHC 4 & $\begin{array}{l}\text { Indoor Pollutant Source } \\
\text { Control }\end{array}$ & 2 \\
\hline IHC 5 & Biological Pollutant & 1 \\
\hline IHC 6 & Visual Comfort & 3 \\
\hline IHC 7 & $\begin{array}{l}\text { Outside View and } \\
\text { Daylight }\end{array}$ & 2 \\
\hline IHC 8 & Thermal Comfort & $2(+2 \mathrm{~B})$ \\
\hline IHC 9 & Acoustic Level & 1 \\
\hline IHC 10 & Interior Plants & 2 \\
\hline IHC 11 & Pest Management & 1 \\
\hline Source: (Gren Buildng Coucil
\end{tabular}

Source: (Green Building Council Indonesia 2017)

An environmentally-friendly office is expected to improve comfortability and ensure a productive environment with more control of operating costs and also improve employees' participation in saving energy, water, and implementing appropriate waste management strategies.



Figure 2. Research object, workspace of Universitas Ciputra lecturers

A workplace needs to consider energy efficiency, new technology, and the occupant's health and comfort in its design. The efforts towards energy-saving are also expected to provide a healthy and comfortable space solution and not to reduce the quality of the indoor environment (Figure 2).

The research was, therefore, conducted to determine the existing condition of the workspace by assessing the Indoor Health and Comfort (IHC) from Greenship Interior Space and suggest design recommendations to achieve a green workplace. This is necessary due to the ability of a well-designed workplace to support employees' performance by improving their productivity and health. This is in agreement with the findings which showed the performance of an occupant is 
determined by several factors supported by a good work environment (Stringer 2010).

Health, Wellbeing and Productivity in Offices: The Next Chapter for Green Building (World Green Building Council 2014) summarizes the health and comfort factors affecting productivity as follows:

1) Indoor Air Quality;

2) Thermal comfort;

3) Daylighting and lighting;

4) Biophilia;

5) Noise;

6) Interior layout;

7) Look and feel;

8) Active design and exercise;

9) Amenities and location.

The Greenship Interior Space criterion is especially beneficial for sustainability and to create healthy and better indoor quality for the occupants. This study was conducted because this was observed to be lacking in several workspaces. Some studies have, however, discussed the Greenship Existing Building at universities (Nurcahyo et al. 2018), users' perception of green buildings with office functions (Mediastika and Lie 2015), research in LEED-certified buildings (Lee and Guerin 2010), factors influencing the comfort level of users in a University (Yahya et al. 2014), indoor health and comfort effects on tenant's productivity (Sakellaris et al. 2016), assessment of IHC in an adaptively reused building (Wardhani and Susan 2019), and strategy to optimize IHC (Susan and Wardhani 2019).

\section{Method}

This research was conducted using the descriptive quantitative method with data collected through observation, interviews, and field measurements. The observations were used to analyze the existing conditions as well as the geometric and lighting assessments. Moreover, the building system was used to determine the (1) no-smoking campaigns (2) introduction of outside air (3) $\mathrm{CO} 2$ monitoring (4) chemical pollutants (5) control of indoor pollutant sources (5) biological pollutants (6) visual comfort (7) display outdoor and daylight (8) thermal comfort (9) acoustic level (10) interior plants (11) pest management, and (12) room occupant survey. The case study for this research was Ciputra University, Indonesia.
Several instruments were used to collect data and this involved the application of lighting assessments to measure visual comfort and daylight through lux values at grid points in range 1.00 to 1.20 meter using lux meter. The thermal comfort was evaluated using a digital room thermometer to determine the temperature and relative humidity inside the room while the acoustic level was measured through the use of a decibel meter.

The results from the observation and measurements were compared with the Greenship Interior Space standards and the discrepancies were used in improving and modifying building systems.

\section{Result and discussion}

\section{Indoor health and comfort assement}

The observation and measurements from the existing Indoor Health and Comfort in the workspace at Ciputra University are explained as follows:

1) No smoking campaigns

This prerequisite criterion for Indoor Health and Comfort has been fulfilled by the commitment of management to set all rooms in the university smoke-free. No-smoking campaigns are also being conducted in the form of stickers placed in several areas in the university.

\section{2) Outdoor air introduction}

The workplace has access to outside air from the window but they are rarely opened to avoid the public glare. This, therefore, means this criterion has not been fulfilled.

\section{3) $\mathrm{CO} 2$ monitoring}

This criterion has not been satisfied due to the consideration of the workspace not to have highdensity and this means there is no need for $\mathrm{CO} 2$ sensors to prevent shortages of fresh air and maintain the health of the occupants. It has been discovered that good indoor air quality, low levels of $\mathrm{CO} 2$, and high levels of ventilation have the ability to improve productivity by $8-11 \%$. Meanwhile, $\mathrm{CO} 2$ levels are used in measuring air quality and have been found to be causing fatigue when the value is high. This has also been reported in several studies to have negative effects 
on memory and concentration (Bakó-Biró et al. 2012).

4) Chemical pollutant

The wall is made of $10 \mathrm{~cm}$ light brick and a 12 $\mathrm{cm}$ plastering finish for the outer wall while the inner wall is painted using paints free from heavy metals and mercury and this means they are safe for the health of the occupants. Moreover, the exposed ceilings were finished with paint having very low VOC content while the floor is decorated with Homogenous Tile $60 \times 60 \mathrm{~cm}$ in natural white color. There is no asbestos in the interior parts of the building and all the materials selected and used were observed to have fulfilled the chemical pollutant criteria and were awarded 7 points. Meanwhile, the furniture has some adhesive contents with high contents of VOC and formaldehyde.

\section{5) Indoor pollutant source control}

The workspace does not meet this criterion due to the lack of access to an exterior because it is located on the 5th floor.

\section{6) Biological pollutant}

There is a need to reduce biological contamination in space in order to maintain the health of the occupants. It is, however, impossible to achieve this criterion due to the lack of appropriate documentation on the cleaning of air conditioning ducts by the building management.

\section{7) Visual comfort}

This criterion aims to ensure appropriate lighting is in the workplace to aid the productivity and comfort of the occupants. The window in the workroom was observed to be facing east and this limits the optimal use of daylight during working hours (8 AM-4 PM) due to the closure of the window to avoid glare. Artificial lighting is usually used instead to provide illumination and this was measured with a lux meter.

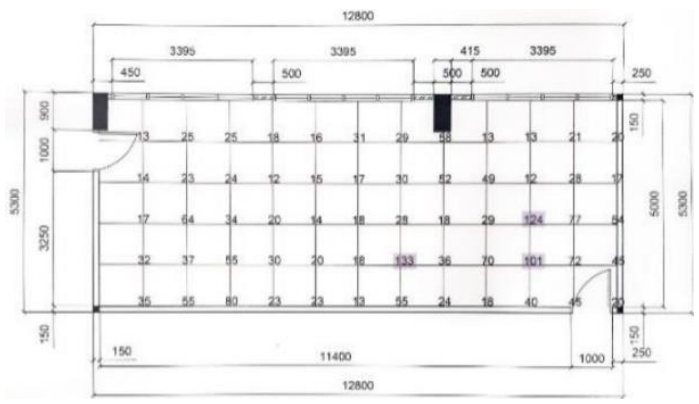

Figure 3. Artificial light illuminance grid

The results showed the artificial lighting is unable to meet the level of illumination suitable for the workspace as observed from the 350-lux recorded. This value makes the light produced to be dim, thereby, causing the eyes to get tired quickly.

There is also no individual lighting system and curtain management integrated with the natural lighting system in the room. The results of field observations and measurements showed this criterion does not satisfy the required benchmarks.

8) Outside view and daylight

A window is placed along the walls of the workplace which is directly oriented to the outside view but the arrangement of the workstation and furniture limits the access. The results showed the outside view covered $55.9 \%$ of the total area. There is, therefore, the need to carefully design the height of the partitions in the workplace to improve employee performance and environmental satisfaction (Lee and Guerin 2010).

The natural light intensity in the workplace is not up to 300 lux and this is associated with the window along the walls facing east and the outside wall covered with secondary skin to reduce the solar radiation but which further limits the sunlight entering the building.

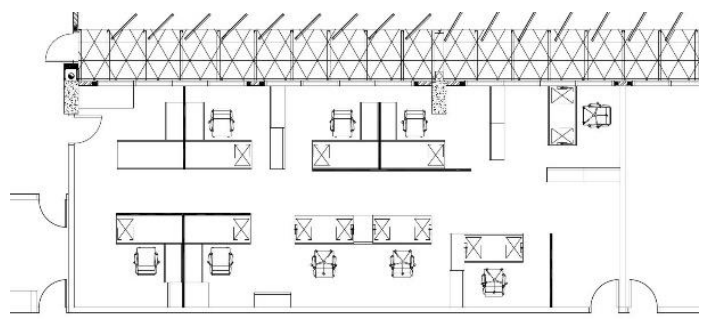

Figure 4. Workplace layout 


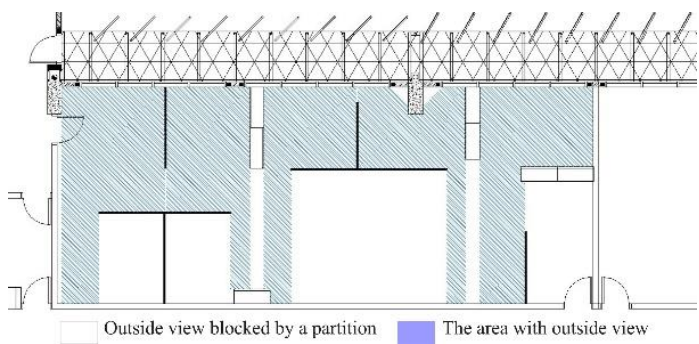

Figure 5. The area with outside view

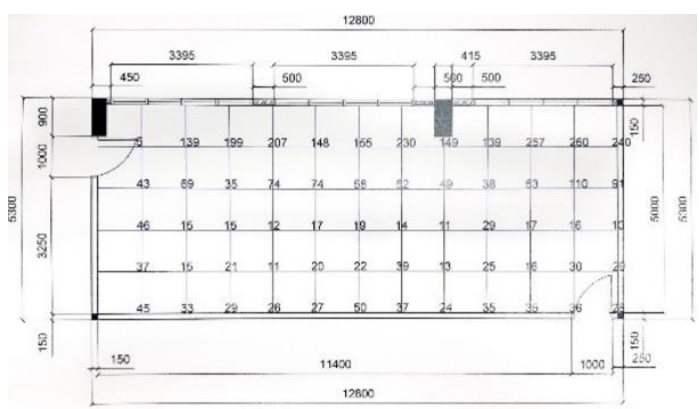

Figure 6. Daylight illuminance grid

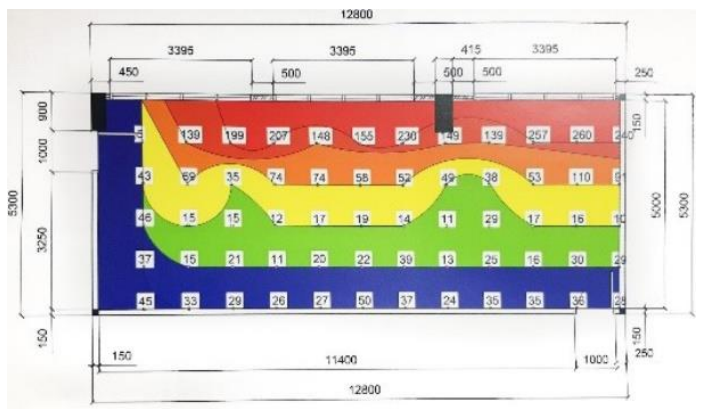

Figure 7. Isocontour graph

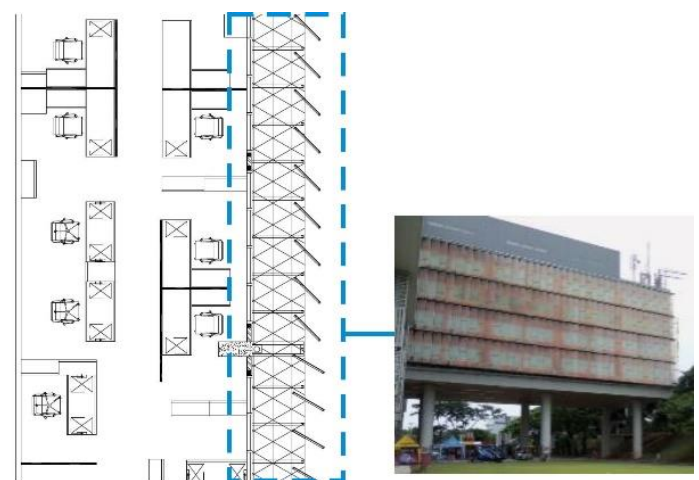

Figure 8. Secondary skin outside the building

The two benchmarks for this criterion are not fulfilled. Meanwhile, several studies have shown an increase in productivity due to the proximity to windows with the most significant factor being the outside views, especially those that connect with nature (World Green Building Council
2014). Therefore, there is a need to optimize daylighting in the workplace due to the ability of natural lights as one of the potential passive strategies to save energy and improve the visual comfort of the occupants without having to spend more on installation and operations (Lim et al. 2012).

\section{9) Thermal comfort}

This criterion aims to ensure a stable condition in the room temperature to improve user productivity. The observations showed the workplace temperature and humidity were not set in line with greenship benchmark which is $25^{\circ} \mathrm{C}$ $\pm 1{ }^{\circ} \mathrm{C}$ and $60 \% \pm 10 \%$ respectively. Moreover, the artificial ventilation system includes 2 split air conditioners placed at the end of the room and are observed not to be an effective cooling spot for individuals. This means both benchmarks required for this criterion are not fulfilled. It is, however, possible to achieve thermal comfort using energy-saving efforts by optimizing the air conditioner to have a good distribution pattern. There are three types of distribution which are perfect mixing, displacement, and radiant cooling. The displacement type has been discovered to be the most rapid to achieve thermal comfort due to its ability to directly drain cold air $30-40 \mathrm{~cm}$ above the floor and has a direct effect on the user's work area by moving heat to the top where no one resides (Seputra 2018). Previous research showed thermal comfort has an effect on employee satisfaction and its control has the ability to improve productivity.

10) Acoustic level

The noise level in $90 \%$ of the area is $40 \mathrm{dBA}$ and this does not meet the design criteria recommended by SNI 03-6386-2000 which is 30$35 \mathrm{dBA}$. This, therefore, makes it difficult to be productive in the office area due to the discomfort caused by the noise. Meanwhile, even though the value does not meet the required SNI level, a background sound at $45 \mathrm{dBA}$ is recommended for an open-plan and 40dBA for private or cellular office (World Green Building Council 2014).

\section{1) Interior plants}

There are no indoor plants to enhance the environmental quality of the interiors and the decreased stress level was reported to be as a result of the access to green open space (Lottrup, Grahn, and Stigsdotter 2013). The occupants of the workplace with indoor plants have better 
mood levels and feel comfortable in space than rooms without plants (Larsen et al. 1998).

\section{2) Pest management}

The building management has implemented periodic pest control with the principle of accuracy in materials, tools, time, and applicators.

\section{3) Room occupant survey}

Building management has not conducted a survey to measure occupant's comfort in order to determine the effect of the design on building operating systems. It is, however, recommended to integrate building assessment, inspection, questionnaire, and environmental measurements to ensure better indoor quality (Carrer and Wolkoff 2018).

The analysis showed the workspace only meets the standard for IHC 3, chemical pollutants, IHC 11, and pest management. Therefore, only 8 points were achieved from the maximum point of 29 achievable.

\section{Strategies towards ensuring green workplace}

Green workplaces can be highly productive and directly contribute to the bottom line. This is associated with the fact that environments with the ability to promote human productivity have a competitive advantage. Several factors have been identified in developing spaces to help workers to be productive and successful in their job. The transformation to a high-performance green workplace is one of these factors due to its ability to improve employee productivity as well as to reduce office operational cost and business carbon footprint (Heck et al. 2012).

Several points are suggested to improve the lecturer green workplace in Ciputra University based on the results from the Indoor Health and Comfort assessment. This involves physical attributes such as connection to nature, exercise ability, sensory change and variability ability, personal environmental control, and good indoor air quality (Stringer 2010).

\section{Connection to nature.}

Human beings have a deep connection to nature which is specifically associated with natural light, access to outside view, landscape features such as vegetation and water as well as the use of natural materials in the interior aspect. Moreover, the environment and its contents are interconnected as one entity and this means there is a need for its preservation (Widodo 2019).
Indoors plants in the form of plants in pots or green walls are proposed to be added to the existing workspace to bring nature closer to the occupants.

\section{Ability to exercise.}

The building design has the ability to promote exercise through open interior stairs, tempting natural walking paths, and in-house fitness facilities. The exposure to fitness not only encourages innovation and concentration but also decreases sick days and long-term corporate healthcare costs. It is proposed that posters or morals be pasted on the existing workspace to encourage the use of stairs as vertical transportation to keep the occupants active and healthy.

\section{Sensory change and variability}

A lack of visual stimuli benumbs the senses during the day and this hinders the ability of a worker to remain alert. Moreover, an inconducive work environment makes workers lose concentration and creative capacity. A workplace with an atmosphere without sensory stimulation usually leads to passivity. The optimization of daylight exposure through windows along the wall and an integrated curtain system to prevent glare is proposed in the new workplace.

\section{Personal control}

There is a need for the personal control of the occupants over noise, lighting, desk height as well as a desk and chair adjustability. It is, therefore, proposed that old furniture be replaced with adjustable tables and chairs and additional task lighting should be provided on each workstation to ensure personal control over lighting.

\section{Indoor air quality}

Sick building syndrome is the common name given to the negative effects of poor air quality in the workplace. It is, however, possible to prevent it mainly by the strict use of green cleaning methods, maintenance of ventilation and air conditioning (HVAC), selection of green materials and furniture systems, enhanced outside air circulation, proper scheduling of construction, and proper design of the building envelope. The existing workspace is proposed to have an additional exhaust fan to supply fresh air while green materials are to be selected for furniture finishing. 
Some other productivity inhibitors observed include noise, visual distractions, and interruptions (Stringer 2010).

\section{Acoustic and visual distractions}

Open-office environments which are working spaces with few enclosed offices and full-height walls are increasingly becoming popular. They are usually considered "greener" due to their less need for artificial light, resources, and ventilation. It makes it easy for employees to see and hear each other more frequently and this usually leads to better communication. This is considered positive for organizational efficiency but has the ability to reduce productivity, particularly when workers attempt to perform tasks requiring a high degree of concentration. A private space with visual and acoustic divider and accessible for occupants to conduct work and meeting requiring high concentration is proposed to be added to the existing workspace.

\section{Glare}

The side effect of maximizing windows and daylight is the glare it produces on computer monitors. This means natural light sometimes has negative effects on productivity. It is, however, possible to avoid this situation through appropriate building orientation, window treatments, and other construction techniques. An automatic integrated curtain system is, therefore, proposed to be added to the existing workplace to avoid glare from daylight exposure.

\section{Interruptions}

Interruptions during basic and regular tasks are stimulus required to continue moving forward. It also has the ability to reduce the motivation to resume work due to the longer time to reorient. The workers are, therefore, proposed to be provided with access to a variety of spaces to work remotely, avoid distractions, and improve their effectiveness.

\section{Conclusion}

The Universitas Ciputra workplace for lecturers has several potentials, especially in the use of natural lighting by replacing the shading device with task lighting to achieve illuminance required by standards. It is also possible to maximize the outside view by changing the partition layout used as a barrier between the workstations. The results also showed a workplace should not focus only on the environmentally and socially conscious behavior but also support employee performance to improve productivity. Moreover, green workplaces also need to ensure effective and wise resources by staying lean and appropriately sized to support greater environmental responsibility. It is also expected to be a way to create better environmental quality for the employees without abandoning their health and productivity.

\section{References}

Bakó-Biró, Zs., D.J. Clements-Croome, N. Kochhar, H.B. Awbi, and M.J. Williams. 2012. 'Ventilation Rates in Schools and Pupils' Performance'. Building and Environment 48 (February): 215-23. https://doi.org/10.1016/j.buildenv.2011.08.01 8.

Carrer, Paolo, and Peder Wolkoff. 2018. 'Assessment of Indoor Air Quality Problems in Office-Like Environments: Role of Occupational Health Services'. International Journal of Environmental Research and Public Health 15 (4): 741. https://doi.org/10.3390/ijerph15040741.

Darus, Fairus Muhamad, Azni Zain Ahmed, and Mohd Talib Latif. 2011. 'Preliminary Assessment of Indoor Air Quality in Terrace Houses'. Environmental Science 2 (2): 8-14.

GBI. 2014. 'Green Building Index'. www. greenbuildingindex.org.

Green Building Council Indonesia. 2017. 'ACHIEVEMENT of Green Building Council Indonesia 2016 - 2017 1'.

Heck, Eric van, Nick van der Meulen, Peter van Baalen, and Marcel van Oosterhout. 2012. 'Achieving High Performance in a Mobile and Green Workplace: Lessons from Microsoft Netherlands'. MIS Quarterly Executive 11 (4): $175-88$.

Larsen, Larissa, Jeffrey Adams, Brian Deal, Byoung Suk Kweon, and Elizabeth Tyler. 1998. 'Plants in the Workplace'. Environment and Behavior 30 (3): 261-81. https://doi.org/10.1177/00139165980300030 1.

Lee, Young S., and Denise A. Guerin. 2010. 'Indoor Environmental Quality Differences between Office Types in LEED-Certified 
Buildings in the US'. Building and Environment $\quad 45 \quad$ (5): $1104-12$. https://doi.org/10.1016/j.buildenv.2009.10.01 9.

Lim, Yaik-Wah, Mohd Zin Kandar, Mohd Hamdan Ahmad, Dilshan Remaz Ossen, and Aminatuzuhariah Megat Abdullah. 2012. 'Building Façade Design for Daylighting Quality in Typical Government Office Building'. Building and Environment 57 (November):

194-204. https://doi.org/10.1016/j.buildenv.2012.04.01 5.

Lottrup, Lene, Patrik Grahn, and Ulrika K. Stigsdotter. 2013. 'Workplace Greenery and Perceived Level of Stress: Benefits of Access to a Green Outdoor Environment at the Workplace'. Landscape and Urban Planning 110 (February): 5-11. https://doi.org/10.1016/j.landurbplan.2012.09 .002 .

Mediastika, Christina, and Karen Lie. 2015. 'Occupants' Perception on Green-Rated Office Building in Surabaya, Indonesia'. Procedia Engineering 118: 546-53. https://doi.org/10.1016/j.proeng.2015.08.479.

Nurcahyo, Rahmat, Nurmala Sari, Muhammad Habiburrahman, and Ellia Kristiningrum. 2018. 'Green Building Standard Assessment at a Higher Education Institution'. Edited by B. Purwanggono and D. Hatta Fudholi. SHS Web of Conferences 49 (October): 01001. https://doi.org/10.1051/shsconf/20184901001

Pradono, Budi. 2019. 'The Interiority of Proximity Between Nature and Architecture in Contemporary and Tropically Context with Cases Studies'. ARTEKS: Jurnal Teknik Arsitektur 3 (2): 129-44. https://doi.org/10.30822/arteks.v3i2.63.

Sakellaris, Ioannis, Dikaia Saraga, Corinne Mandin, Célina Roda, Serena Fossati, Yvonne de Kluizenaar, Paolo Carrer, et al. 2016. 'Perceived Indoor Environment and Occupants' Comfort in European "Modern" Office Buildings: The OFFICAIR Study'. International Journal of Environmental Research and Public Health 13 (5): 444. https://doi.org/10.3390/ijerph13050444.

Seputra, Jackobus Ade Prasetya. 2018. 'Kajian Numerik Distribusi Udara Pada Ruang Ber-
AC Untuk Mencapai Tingkat Efisisensi Energi Yang Optimal'. ARTEKS: Jurnal Teknik Arsitektur 3 (1): 45-56. https://doi.org/10.30822/arteks.v3i1.53.

Stringer, Leigh. 2010. 'The Green Workplace: Sustainable Strategies That Benefit Employees, the Environment, and the Bottom Line'. Choice Reviews Online 47 (08): 474512-47-4512. https://doi.org/10.5860/CHOICE.47-4512.

Subroto, Tarcicius Yoyok Wahyu. 2019. 'Koeksistensi Alam Dan Budaya Dalam Arsitektur'. ARTEKS: Jurnal Teknik Arsitektur 3 (2). https://doi.org/10.30822/arteks.v3i2.60.

Susan, and Dyah Kusuma Wardhani. 2019. 'Enhancing Indoor Health Comfort in Adaptively Reused Heritage Building'. In Proceedings of the Annual International Conference on Architecture and Civil Engineering.

Wardhani, Dyah Kusuma, and Susan. 2019. 'Greenship Assessment of Indoor Health Comfort in Adaptive Reused Building'. In Proceedings of the Annual International Conference on Architecture and Civil Engineering.

Widodo, Johannes. 2019. 'Human, Nature, And Architecture'. ARTEKS: Jurnal Teknik Arsitektur 3 (2): 145-48. https://doi.org/10.30822/arteks.v3i2.65.

World Green Building Council. 2013. 'The Business Case for Green Building: A Review of the Costs and Benefits for Developers, Investors and Occupants'. 2013.

. 2014. 'Health, Wellbeing \& Productivity in Offices'. 2014.

Yahya, S. N. N. Syed, Ati Rosemary, Mohd Ariffin, and Muhammad Azzam Ismail. 2014. 'Factors Contributing to Occupants' Comfort: A Survey among Occupants of Academic Buildings in a Public University'. In Proceedings of the 2014 International Conference Engineering and Operations Management.

Yuliani, Sri, Gagoek Hardiman, and Erni Setyowati. 2020. 'Pemetaan Hasil Penelitian Atap Hijau Dalam Disiplin Ilmu Arsitektur Di Indonesia'. ARTEKS: Jurnal Teknik Arsitektur 5 (2): 245-54. https://doi.org/10.30822/arteks.v5i2.395. 